\title{
The impact of measures aimed at reducing low-stack emission in Poland and on energy efficiency and the household emission of pollutants
}

ABSTRACT: According to the European Environment Agency (EEA 2018), air quality in Poland is one of the worst in Europe. There are several sources of air pollution, but the condition of the air in Poland is primarily the result of the so-called low-stack emissions from the household sector. The main reason for the emission of pollutants is the combustion of low-quality fuels (mainly low-quality coal) and waste, and the use of obsolete heating boilers with low efficiency and without appropriate filters. The aim of the study was to evaluate the impact of measures aimed at reducing low-stack emissions from the household sector (boiler replacement, change of fuel type, and thermal insulation of buildings), resulting from environmental regulations, on the improvement of energy efficiency and the emission of pollutants from the household sector in Poland.

Stochastic energy and mass balance models for a hypothetical household, which were used to assess the impact of remedial actions on the energy efficiency and emission of pollutants, have been developed. The annual energy consumption and emissions of pollutants were estimated for hypothetical households before and after the implementation of a given remedial action. The calculations, using

$\bowtie$ Corresponding Author: Dominik Kryzia; e-mail: kryzia@min-pan.krakow.pl

1 Mineral and Energy Economy Research Institute of the Polish Academy of Sciences, Krakow, Poland; ORCID iD: 0000-0003-0639-3485; e-mail: kryzia@min-pan.krakow.pl

2 Mineral and Energy Economy Research Institute of the Polish Academy of Sciences, Krakow, Poland; ORCID iD: 0000-0001-9150-7525; e-mail: monika@min-pan.krakow.pl

2019. The Author(s). This is an open-access article distributed under the terms of the Creative Commons Attribution-ShareAlike International License (CC BY-SA 4.0, http://creativecommons.org/licenses/by-sa/4.0/), which permits use, distribution, and reproduction in any medium, provided that the Article is properly cited. 
the Monte Carlo simulation, were carried out for several thousand hypothetical households, for which the values of the technical parameters (type of residential building, residential building area, unitary energy demand for heating, type of heat source) were randomly drawn from probability distributions developed on the basis of the analysis of the domestic structure of households. The model takes the coefficients of correlation between the explanatory variables in the model into account. The obtained results were multiplied so that the number of hypothetical households was equal to 14.1 million, i.e. the real number of households in Poland.

The obtained results allowed for identifying the potential for reducing the emission of pollutants such as carbon dioxide, carbon monoxide, dust, and nitrogen oxides, and improving the energy efficiency as a result of the proposed and implemented measures, aimed at reducing low-stack emission, resulting from the policy.

The potential for emissions of gaseous pollutants is $94 \%$ for $\mathrm{CO}, 49 \%$ for $\mathrm{NO}_{\mathrm{x}}, 90 \%$ for dust, and $87 \%$ for $\mathrm{SO}_{2}$. The potential for improving the energy efficiency in households is around $42 \%$.

KEYWORDS: energy efficiency, Monte Carlo simulation, households, low-stack emission

\section{Introduction}

According to the European Environment Agency (EEA 2018), the air quality in Poland is one of the worst in Europe. There are several sources of air pollution, but the condition of the air in Poland is primarily the result of the so-called low-stack emissions from the household sector. $88 \%$ of air pollution, mainly dust pollutants, is generated by households (ME 2015). Other sources of pollution include: transport, industry, power generation using solid fuels, and agriculture. Low-stack emissions are a source of air pollutants, such as, among others: dust, carbon oxides, sulphur dioxide, nitrogen oxides and benzo(a)pyrene. The main reason for the emission of these pollutants in Poland is the combustion of low-quality fuels (mainly low-quality coal) and waste, and the use of obsolete heating boilers with low efficiency and without appropriate filters.

To make it possible to live in a healthy environment and breathe clean air, national, regional, and local authorities make efforts in order to control and improve the air quality. The replacement of old, low-efficiency heating systems could be one of the most important and effective measures. This action has a significant ecological effect and is of high economic efficiency (WB 2018). Other important corrective actions include: changing the type of fuel used for the production of heat and hot tap water into low-carbon fuel and the energy efficiency improvement of buildings through thermal insulation. Energy efficiency is one of the main assumptions of the Europe 2020 strategy aimed at reducing the primary energy consumption by $20 \%$ in 2020 compared to the 1990 level. Due to the fact that the energy-related emissions account for almost $80 \%$ of total greenhouse gas emissions, efficient energy use can significantly contribute to environmental improvements. In Poland, approximately $34 \%$ of the total energy is used for household needs, of which $80 \%$ is used for heating purposes (Zawada and Starostka-Patyk 2016). 
The authors of the article decided to assess the measurable effect, that is the reduction of pollutant emissions to the atmosphere, of the proposed corrective actions. Therefore, the aim of the study was to evaluate the impact of measures aimed at reducing low-stack emissions from the household sector (boiler replacement, change of fuel type, and thermal insulation of buildings), resulting from environmental regulations, on the improvement of energy efficiency and the emission of pollutants from the household sector in Poland. This is the first study to use stochastic modeling to assess the potential for reducing the emissions of pollutants and improving the energy efficiency in the household sector in Poland. The following pollutants were analyzed: dust, carbon monoxide, sulphur dioxide, and nitrogen oxides.

This analysis is justified in the context of the Regional Operational Programs of Poland's Provinces in the household area supported by national and EU funds, which adopted measures aimed at improving the energy efficiency and air quality through air quality through thermal efficiency improvement and co-financing the replacement of old coal-fired boilers with environmentally-friendly heating sources. Funds for these purposes should be spent rationally. Up to now, most of these funds were used to implement projects aimed at replacing coal-fired boilers/ furnaces with low-carbon heat sources, including: gas boilers, district heating, or eco-pea coal or biomass boilers (Mirowski and Orzechowska 2015). The analysis carried out allowed for the verification as to whether this course of action is optimal in the context of improving the air quality and energy efficiency.

\section{The model, input data, and calculations}

For the purpose of the analysis, stochastic energy and mass balance models for a hypothetical household, which were used to assess the potential to improve the energy efficiency and reduce the emission of pollutants as a result of corrective actions, have been developed. The annual energy consumption and emission of pollutants were estimated for hypothetical households before and after the implementation of a given corrective measure. The three possible corrective actions to be implemented in the household sector and consistent with policies and regulations were listed. They include (Sadlok et al. 2014):

1. Replacing coal-fired individual boilers with other heat sources such as: district heating, biomass boilers, or gas boilers.

2. Replacing manually operated coal-fired boilers with class 5 (or more environmentally friendly) eco-pea fired boilers with automatic feeder.

3. Thermal efficiency improvement of buildings, including: thermal insulation of external partitions, replacement of doors and windows, and upgrading ventilation and air-conditioning systems, which will result in the maximum heat demand of $150 \mathrm{kWh} / \mathrm{m}^{2}$ per year (SZOOP 2017). 
Regulations related to environmental protection are another important element affecting the use of coal in households. One of the legal acts that may contribute to reducing the use of coal in households is the so-called Anti-Smog Act. It was introduced in 2015 by amending the Environmental Protection Law (EPL 2001). According to the Act, the decision to limit or prohibit the combustion of certain solid fuels depends on the resolution of the Provincial Assembly. Another legislative act that will affect the use of coal in households is the Regulation of the Minister of Development on the requirements for solid fuel boilers with a capacity of maximum $500 \mathrm{~kW}$ (MEDF 2017). Solid fuel boilers meeting the emission limit values are specified in the Regulation. This regulation will come into force on January 1, 2018.

The calculations, using the Monte Carlo simulation, were carried out for 14 thousand hypothetical households, for which the values of the technical parameters were randomly drawn from probability distributions developed on the basis of the analysis of the domestic structure of households. The following technical parameters characterizing a household were adopted in the analysis:

\ The type of residential building (single family house, apartment in a multi-family building);

$\checkmark$ Year of the building's construction;

- The unit demand for heating energy expressed in kilowatt hours per square meter per year;

$\checkmark$ Dwelling area in square meters;

- Heat source type (district heating from coal-fired heating plant or combined heat and power plant, natural gas fired boiler, manually operated coal-fired boiler, class 5 (or more environmentally friendly) automatically operated coal-fired boiler, heating oil-fired boiler, biomass (pellet) fired boiler, or electric furnace).

Statistical data of the Central Statistical Office indicate that the share of multi-family buildings in the total number of households in Poland amounts to $55.3 \%$. Meanwhile, the share of detached, semi-detached, and terraced houses amounted to 44.7\% (CSO 2016).

Table 1 shows the age structure of residential buildings in Poland. The largest share is attributed to houses built after the Second World War up until the year 1970. A small share of just over $9 \%$ is attributed to the oldest buildings, built before 1918. New residential buildings, meaning those built after the year 2002, have the lowest share. The age of a residential building is strongly correlated with its area and individual heat demand. The analysis carried out has shown that the later the residential building was built, the larger the average area of residential units. The correlation coefficient determined on the basis of statistical data for the age of the building (and hence the unit energy demand) and the average surface area of the premises is 0.75 . Table 1 presents the primary energy demand for household heating. The demand increases with the age of the building. This is due to changes in energy standards in the household sector. At the same time over $92 \%$ of the buildings have a medium, low or very low energy standard.

Table 2 shows the structure of residential space in Poland. It is dominated by residential premises with an area of 40 to $80 \mathrm{~m}^{2}$, which account for $52.3 \%$ of all residential units. Residential units in single-family homes are larger than those in multi-family buildings, on average by about 26\% (Local Data Bank of Central Statistical Office). 
TABLE 1 . The age structure of residential buildings and the unit demand for primary energy

TABELA 1. Struktura wiekowa budynków mieszkalnych i jednostkowe zapotrzebowanie na energię pierwotną

\begin{tabular}{|c|c|c|c|c|}
\hline No. & Year of construction & Percentage share & $\begin{array}{c}\text { Minimum heat demand } \\
{\left[\mathrm{kWh} /\left(\mathrm{m}^{2 *} \text { year }\right)\right]}\end{array}$ & $\begin{array}{c}\text { Maximum heat demand } \\
{\left[\mathrm{kWh} /\left(\mathrm{m}^{2 *} \text { year }\right)\right]}\end{array}$ \\
\hline 1 & before 1918 & 9.01 & 350 & 500 \\
\hline 2 & $1918-1944$ & 11.46 & 300 & 350 \\
\hline 3 & $1945-1970$ & 27.62 & 250 & 300 \\
\hline 4 & $1971-1978$ & 16.08 & 210 & 250 \\
\hline 5 & $1979-1988$ & 16.38 & 160 & 210 \\
\hline 6 & $1989-2002$ & 11.31 & 140 & 180 \\
\hline 7 & $2003-$ now & 8.14 & 100 & 150 \\
\hline
\end{tabular}

Source: (CM 2015, CSO 2011).

TABLE 2. The structure of residential space

TABELA 2. Struktura powierzchni lokalów mieszkalnych

\begin{tabular}{|c|c|c|}
\hline No. & $\begin{array}{c}\text { The area of residential premises } \\
{\left[\mathrm{m}^{2}\right]}\end{array}$ & Percentage share \\
\hline 1 & below 30 & 4.3 \\
\hline 2 & $30-40$ & 12.2 \\
\hline 3 & $40-50$ & 18.1 \\
\hline 4 & $50-60$ & 15.3 \\
\hline 5 & $60-80$ & 18.9 \\
\hline 6 & $80-100$ & 8.9 \\
\hline 7 & $100-120$ & 7.7 \\
\hline 8 & $120-200$ & 9.5 \\
\hline 9 & over 200 & 2.8 \\
\hline
\end{tabular}

Source: (CSO 2011).

Table 3 shows the structure of heat sources in households broken down by building type and the emission of pollutants $\left(\mathrm{SO}_{2}, \mathrm{NO}_{\mathrm{x}}\right.$, dust, and $\left.\mathrm{CO}\right)$, depending on the type of heat source.

Based on the data presented above, the probability density distributions of the individual parameters were prepared, which were used in the simulation model. A total of 5 probability density distributions for the following parameters: the type of residential building, residential building area, unit energy demand for heating, and the type of heat source in single-family houses and households were developed. These distributions were developed on the basis of statistical data characterizing the household sector in Poland. The probability distributions for these parameters are presented below. 
TABLE 3. The structure of heat sources in residential buildings and emission levels

TABELA 3. Struktura źródeł ciepła w lokalach mieszkalnych oraz wielkość emisji

\begin{tabular}{|c|l|c|c|c|c|c|c|}
\hline \multirow{2}{*}{ No. } & \multicolumn{1}{|c|}{ Heat source type } & \multicolumn{2}{c|}{ Percentage share } & \multicolumn{4}{c|}{ Emissions [g/kWh] } \\
\cline { 3 - 9 } & & $\begin{array}{c}\text { single family } \\
\text { houses }\end{array}$ & households & $\mathrm{SO}_{2}$ & $\mathrm{NO}_{\mathrm{x}}$ & dust & CO \\
\hline 1 & District heating (coal-fired heating plants) & 1 & 53 & 0.3381 & 0.1950 & 0.0216 & 0.0833 \\
\hline 2 & Natural gas-fired boilers & 37 & 32 & 0.0018 & 0.2520 & 0.0018 & 0.1080 \\
\hline 3 & Heating oil-fired boilers & 3 & 2 & 0.5040 & 0.2520 & 0.0180 & 0.1440 \\
\hline 4 & $\begin{array}{l}\text { Manually operated coal-fired boilers } \\
\text { (excluding class 5 boilers) }\end{array}$ & 28 & 6 & 3.2401 & 0.4680 & 1.4400 & 14.4004 \\
\hline 5 & $\begin{array}{l}\text { Automatically operated coal-fired boilers } \\
\text { (at least class 5 boilers) }\end{array}$ & 7 & 2 & 1.6200 & 0.7200 & 0.2880 & 1.4400 \\
\hline 6 & Solid biomass-fired boilers & 20 & 1 & 0.0720 & 0.5400 & 0.2520 & 1.0800 \\
\hline 7 & Electrically powered furnaces & 4 & 4 & 0.9017 & 0.5200 & 0.0575 & 0.2222 \\
\hline
\end{tabular}

Source: (BDP 2012; Kubica et al. 2004).

During the simulation, random values characterizing a hypothetical residential building are based on the probability density distributions for the unit energy demand for heating and residential building area. It was assumed that both distributions were correlated and the Pearson's correlation coefficient was 0.75 . The product of both values is the value of the annual demand for heating for the premises ( $\mathrm{kWh}$ per year). The types of heat source were randomized based on the probability distribution of heat sources used in residential buildings. Different probability distributions of the heat source were adopted for single-family houses and dwellings. The type of heat source used determines the amount of emission of individual pollutants (Tab. 3). Knowing the energy demand for residential heating, it is possible to estimate the emissions of individual pollutants generated by a hypothetical household/dwelling. In the next iteration, the process is repeated in the same way, generating emission values for pollutants and heating energy demand for other hypothetical households. As part of the simulation, 14,000 iterations have been performed. The obtained results were multiplied so that the number of hypothetical households was equal to 14.1 million, i.e. the real number of households in Poland. The obtained emission values were summed according to the pollutant category, which allowed obtaining the annual emissions of individual pollutants by households in Poland.

Simulations were performed for five scenarios.

The STATUS QUO scenario - presents the current emissions of pollutants and heating energy demand in the household sector in Poland.

The NO COAL scenario - presents a hypothetical situation after the implementation of actions aimed at replacing coal-fired individual boilers instead of coal-fired heat sources with other heat sources such as: district heating, biomass boilers, or gas boilers. 

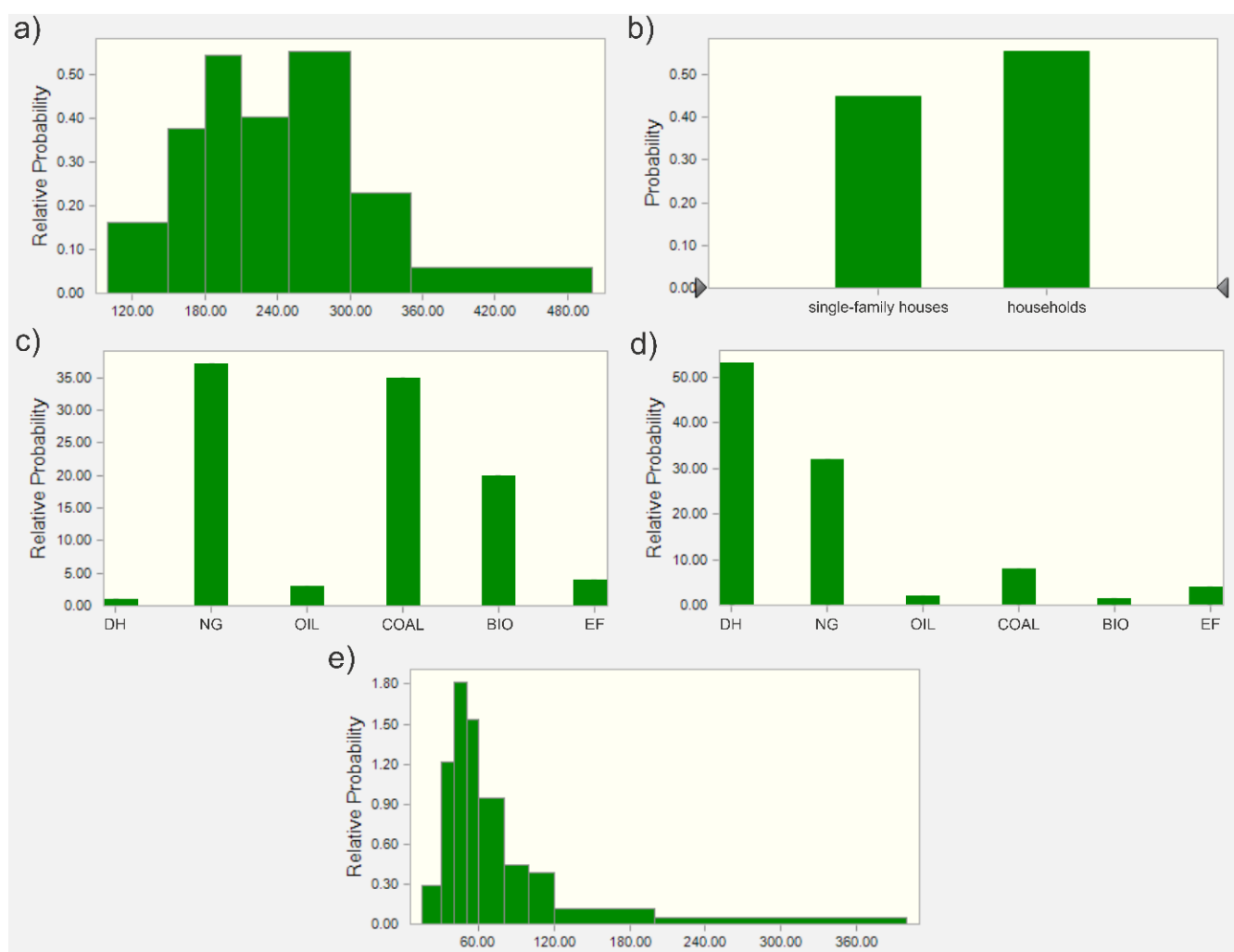

Fig. 1. The probability density distributions for the following parameters:

a) residential building area $\left[\mathrm{m}^{2}\right]$; b) the type of residential building; c) the type of heat source in single-family houses; d) the type of heat source in households; e) unit energy demand for heating $\left[\mathrm{kWh} / \mathrm{m}^{2} / \mathrm{rok}\right]$; DH - district heating; NG - natural gas-fired boilers; OIL - oil-fired boilers; COAL - coal-fired boilers; BIO - solid biomass-fired boilers; $\mathrm{EF}-$ electrically powered furnaces

Source: own study

Rys. 1. Rozkłady gęstości prawdopodobieństwa wartości parametrów:

a) powierzchnia lokalu mieszkalnego $\left[\mathrm{m}^{2}\right]$; b) rodzaj budynku mieszkalnego; c) rodzaj źródła ciepła w domach jednorodzinnych; d) rodzaj źródła ciepła w mieszkaniach; e) jednostkowe zapotrzebowanie na energię do ogrzewania $\left[\mathrm{kWh} / \mathrm{m}^{2} / \mathrm{rok}\right]$

The LOW-CARBON scenario - presents a hypothetical situation after the development and implementation of actions aimed at replacing manually operated coal-fired boilers with class 5 eco-pea fired boilers with automatic feeder.

The THERMO scenario - presents a hypothetical situation after the development and implementation of actions aimed at the thermal efficiency improvement of buildings, including: thermal insulation of external partitions, replacement of doors and windows, and upgrading ventilation and air-conditioning systems, which will result in the maximum heat demand of $150 \mathrm{kWh} / \mathrm{m}^{2}$ per year. 
The MINI scenario - presents a hypothetical situation after the development and implementation of tow actions aimed at the thermal efficiency improvement of buildings, including: thermal insulation of external partitions, replacement of doors and windows, and upgrading ventilation and air-conditioning systems, which will result in the maximum heat demand of $150 \mathrm{kWh} / \mathrm{m}^{2}$ per year and replacing coal-fired boilers with other heat sources such as: district heating, biomass boilers, or gas boilers.

\section{Research and results}

The simulations for each of the analyzed scenarios allowed emission values for individual pollutants and the energy demand for space heating in the domestic household sector to be determined (Table 4). The values obtained for the STATUS QUO scenario are close to those officially reported for the household sector, which confirms that the input data, assumptions, and model design are correct.

TABLE 4. Emissions of pollutants and the heating energy demand in the household sector in Poland

TABELA 4. Wielkość emisji zanieczyszczeń oraz zapotrzebowanie na energie do ogrzewania w sektorze gospodarstw domowych

\begin{tabular}{|c|l|r|r|r|r|c|}
\hline \multirow{2}{*}{ No. } & \multirow{2}{*}{ Scenario name } & \multicolumn{4}{|c|}{ Emission of pollutants [Mg/year] } & \multirow{2}{*}{$\begin{array}{c}\text { Heat demand } \\
\text { [MWh/year] }\end{array}$} \\
\cline { 3 - 6 } & & $\mathrm{CO}$ & $\mathrm{NO}_{\mathrm{x}}$ & \multicolumn{1}{c|}{ dust } & \multicolumn{1}{|c|}{$\mathrm{SO}_{2}$} & \\
\hline 1 & STATUS QUO & 573190.44 & 71824.72 & 62162.43 & 163071.14 & 230035734.66 \\
\hline 2 & NO COAL & 56788.79 & 62951.23 & 10963.71 & 34858.37 & 230035734.66 \\
\hline 3 & LOW-CARBON & 104649.32 & 80955.15 & 20501.80 & 103361.45 & 230035734.66 \\
\hline 4 & TERMO & 338452.66 & 42133.80 & 36656.85 & 95390.53 & 134587965.85 \\
\hline 5 & MINI & 33358.79 & 36857.71 & 6469.76 & 20711.17 & 134498541.93 \\
\hline
\end{tabular}

Source: own study.

Table 5 shows the impact (expressed in percentage) of individual actions implemented under the examined scenarios on emissions and the energy demand in relation to the STATUS QUO scenario.

The obtained results show that the most environmentally friendly solution is the implementation of corrective actions according to the MINI scenario, but this is the most expensive solution, since thermal efficiency improvement is costly and has a relatively limited environmental impact, as confirmed by the emissions for the THERMO scenario. Compared to other analyzed actions, thermal efficiency improvement is best suited for $\mathrm{NO}_{\mathrm{x}}$ emission reduction. Based on the 
TABLE 5. The percentage change in pollutant emissions and the energy demand for heating in relation to the STATUS QUO scenario

TABELA 5. Procentowa zmiana emisji zanieczyszczeń i zapotrzebowania na energię do ogrzewania w stosunku do scenariusza STATUS QUO

\begin{tabular}{|c|l|c|c|c|c|c|}
\hline \multirow{2}{*}{ No. } & \multirow{2}{*}{ Nazwa scenariusza } & \multicolumn{4}{c|}{ Emission of pollutants } & \multirow{2}{*}{ Heat demand } \\
\cline { 3 - 6 } & & $\mathrm{CO}$ & $\mathrm{NO}_{\mathrm{x}}$ & dust & $\mathrm{SO}_{2}$ & \\
\hline 1 & NO COAL & $-90 \%$ & $-12 \%$ & $-82 \%$ & $-79 \%$ & $0 \%$ \\
\hline 2 & LOW-CARBON & $-82 \%$ & $+13 \%$ & $-67 \%$ & $-37 \%$ & $0 \%$ \\
\hline 3 & TERMO & $-41 \%$ & $-41 \%$ & $-41 \%$ & $-42 \%$ & $-42 \%$ \\
\hline 4 & MINI & $-94 \%$ & $-49 \%$ & $-90 \%$ & $-87 \%$ & $-42 \%$ \\
\hline
\end{tabular}

Source: own study.

obtained results, it can be concluded that moving away from coal as a fuel for the production of heat in individual boilers (the NO COAL scenario) will result in a significant reduction of pollutant emissions and thus a very effective corrective action against low-stack emissions. However, Poland is a country with a relatively not wealthy society, so moving away from coal and switching to alternative fuels such as: natural gas, heating oil, or biomass, which are more expensive, will contribute to economic problems in the household sector. Therefore, replacing manually operated coal-fired boilers with class 5 eco-pea fired boilers with automatic feeder seems more favorable. Coal is a relatively inexpensive fuel, so a large part of the community, which has previously used this fuel for space heating, does not want to move away from this energy carrier. Therefore, replacing boilers seems to be more likely to be accepted by the society; at the same time, this solution has a significant ecological effect, reducing the emission of pollutants by $82 \%$ (CO), $67 \%$ (dust), and $37 \%\left(\mathrm{SO}_{2}\right)$. The increase in $\mathrm{NO}_{\mathrm{x}}$ emissions results from a higher combustion temperature due to the use of combustion air blowers in boilers with automatic feeder. $\mathrm{NO}_{\mathrm{x}}$ emissions can be significantly reduced by using boilers meeting the requirements of the Ecodesign Directive.

\section{Summary}

The obtained results allowed for the identification of potential for reducing the emission of pollutants such as: carbon dioxide, carbon monoxide, dust, and nitrogen oxides, and improving the energy efficiency as a result of the proposed and implemented measures, aimed at reducing low -stack emissions. The complete thermal efficiency improvement (with the replacement of the heat source, the MINI scenario) offers the greatest potential in reducing the emission of gaseous pollu- 
tants in the household sector and is up to $94 \%$ for $\mathrm{CO}, 49 \%$ for $\mathrm{NO}_{\mathrm{x}}, 90 \%$ for dust, and $87 \%$ for $\mathrm{SO}_{2}$. Meanwhile, the potential for improving the energy efficiency in households is around $42 \%$.

Due to the high costs of buildings' insulation, the best way to reduce emissions is to convert heat sources to low-carbon ones. This is more economically efficient than the thermal insulation of buildings and, at the same time, is more environmentally friendly as it results in a higher reduction of pollutant emissions.

Summing up the previous considerations, it can be concluded that there is a significant untapped potential for increasing the energy efficiency and reducing the emission of gaseous pollutants from the household sector in Poland. The introduced regulations, the proposed legislative changes, and the implemented programs aimed at reducing low-stack emissions will play an important role in improving the energy efficiency of households and have real effects in reducing the emission of pollutants.

\section{References}

BDP 2012. Report: Energy status of buildings in Poland (Raport: Stan energetyczny budynków w Polsce). Cigacice: BuildDesk Poland (BDP), 18 pp. (in Polish).

CM 2015. Resolution of 22 June 2015 National plan to increase the number of buildings with low energy consumption (Krajowego planu mającego na celu zwiększenie liczby budynków o niskim zużyciu energii). Council of Ministers (CM). (M.P.2015.614) (in Polish).

CSO 2011. National Population and Housing Census 2011 (Narodowy Spis Powszechny Ludności i Mieszkań 2011). Central Statistical Office (CSO). [Online] www.stat.gov.pl [Accessed: 2017-11-02].

CSO 2016. Housing Economy in 2016 (Gospodarka mieszkaniowa w 2016). Central Statistical Office (CSO). [Online] www.stat.gov.pl [Accessed: 2017-11-02].

EEA 2018. Air quality in Europe - 2018 report. Luxembourg: European Environment Agency (EEA), 88 pp.

EPL 2001. Act of 27 April 2001 Environmental Protection Law (Prawo ochrony środowiska). (Dz.U.2001.62.627) (in Polish).

Kubica et al. 2004 - Kubica, K., Paradiz, B., Dilara, P., Klimont, Z., KaKareKa, S. and DębSki, B. 2004. Small Combustion Installations, Chapter for "Emission Inventory Guidebook". UNECE TFEIP, (Updated by Kubica K., and Woodfield M. in 2006), B216-2.

Local Data Bank of Central Statistical Office. [Online] www.stat.gov.pl [Accessed: 2017-11-02].

ME 2015. The National Programme for air protection to 2020 (with the prospect of 2030) (Krajowy program ochrony powietrza do roku 2020 (z perspektywa do 2030)). Warszawa: Ministry of the Environment (ME), 90 pp. (in Polish).

MEDF 2017. Regulation of the Minister for Economic Development and Finance of 1 August 2017 on the requirements for solid-fuel boilers (Rozporządzenie Ministra Rozwoju i Finansów z dnia 1 sierpnia 2017 r. w sprawie wymagań dla kottów na paliwo state) (Dz.U.2017.1690) (in Polish).

MirowsKi, T. and ORZECHOWSKA, M. 2015. The use of biomass fuels in individual heating in areas threatened by low emission (Wykorzystanie paliw biomasowych $w$ ogrzewnictwie indywidualnym na obszarach zagrożonych niska emisja). Polityka Energetyczna - Energy Policy Journal 18(4), pp. 75-88 (in Polish).

SAdLOK et al. 2014 - SAdloK, R., Graboś, A., ŻYMANKOWSKA-Kumon, S. and SADlOK, J. 2014. Preventing low emissions in areas of compact residential buildings (Przeciwdziatanie niskiej emisji na terenach zwartej zabudowy mieszkalnej). HELIOS, 112 pp. (in Polish). 
SZOOP 2017. A detailed description of the Regional Operational Programs of Małopolskie Voivodship 2014-2020 (Szczegółowy opis osi priorytetowych Regionalnego Programu Operacyjnego Województwa Małopolskiego na lata 2014-2020). Urząd Marszałkowski Województwa Małopolskiego, Kraków, 343 pp. (in Polish).

WB 2018. Report: Smog-fighting. Financial Instruments for Energy Efficiency of single-family houses (Raport: Walka ze smogiem: Instrumenty finansowe dla podnoszenia efektywności energetycznej budynków jednorodzinnych). The World Bank, 139 pp. (in Polish).

Zawada, M. and StarostKa-PatyK, M. 2016. Energy Efficiency in the Context of Low-stack Emissions Reduction on the Example of the City of Czestochowa. Transportation Research Procedia 16/2016, pp. 587-597.

\section{Wpływ działań zmierzających do ograniczenia niskiej emisji w Polsce na efektywność energetyczną i emisję polutantów w gospodarstwach domowych}

\section{Streszczenie}

Celem pracy była ocena wpływu działań zmierzających do obniżenia niskiej emisji w gospodarstwach domowych (wymiana kotłów, zmiana rodzaju paliwa, docieplenie budynków) wynikających z regulacji prawnych w zakresie ochrony środowiska na poprawę efektywności energetycznej i emisję polutantów w sektorze gospodarstw domowych w Polsce. Zbudowano stochastyczne modele bilansu energii i masy dla hipotetycznego gospodarstwa domowego, które zostały wykorzystane do oceny efektywności energetycznej i emisji polutantów realizacji działań wynikających z prawodawstwa. Dla hipotetycznych gospodarstw domowych oszacowane zostało roczne zużycie energii i emisji polutantów przed wdrożeniem danej regulacji i po jej wdrożeniu. Wykorzystując symulację Monte Carlo obliczenia zostały przeprowadzone dla kilku tysięcy hipotetycznych gospodarstw domowych, dla których wartości parametrów technicznych (liczba osób w gospodarstwie, sposób przygotowania ciepłej wody użytkowej i ogrzewania budynku, rodzaj paliwa, wiek i klasa energetyczna budynku, powierzchnia i lokalizacja budynku) były losowane z rozkładów prawdopodobieństwa przygotowanych na podstawie analizy struktury krajowej gospodarstw domowych. Otrzymane wyniki zwielokrotniono tak, aby liczba hipotetycznych gospodarstw była równa $14,1 \mathrm{mln}$, tj. rzeczywistej liczbie gospodarstw domowych w Polsce. Otrzymane wyniki pozwoliły określić potencjał w zakresie ograniczenia emisji polutantów takich jak $\mathrm{CO}_{2}, \mathrm{CO}$, pyły oraz $\mathrm{NO}_{\mathrm{x}}$ i poprawy efektywności energetycznej w wyniku proponowanych i realizowanych działań zmierzających do ograniczenia niskiej emisji wynikających z regulacji prawnych. Potencjał emisję zanieczyszczeń gazowych sięga ponad 94\%, natomiast potencjał w zakresie poprawy efektywności energetycznej w gospodarstwach domowych wynosi około $42 \%$.

SŁOWA KLUCZOWE: efektywność energetyczna, symulacja Monte Carlo, gospodarstwa domowe, niska emisja 
